10-1-1969

\title{
Patterns and determinants of income of canadian engineering graduates
}

Andrew C. Gross

Cleveland State University, a.gross@csuohio.edu

Follow this and additional works at: https://engagedscholarship.csuohio.edu/busmarkt_facpub

Part of the Human Resources Management Commons, and the International Business Commons How does access to this work benefit you? Let us know!

\section{Publisher's Statement}

@ 1969 Cornell University

\section{Original Citation}

Gross, A. C. (1969). PATTERNS AND DETERMINANTS OF INCOME OF CANADIAN ENGINEERING

GRADUATES. Industrial \& Labor Relations Review, 23(1), 52-64.

\section{Repository Citation}

Gross, Andrew C., "Patterns and determinants of income of canadian engineering graduates" (1969). Marketing. 1. https://engagedscholarship.csuohio.edu/busmarkt_facpub/1

This Article is brought to you for free and open access by the Browse Business Faculty Books and Publications by Topic at EngagedScholarship@CSU. It has been accepted for inclusion in Marketing by an authorized administrator of EngagedScholarship@CSU. For more information, please contact library.es@csuohio.edu. 


\title{
PATTERNS AND DETERMINANTS OF INCOME OF CANADIAN ENGINEERING GRADUATES
}

\author{
ANDREW C. GROSS
}

$\mathrm{T}$ HIS report describes and seeks explanations for the salary structure of college graduates who received their bachelor's degrees in electrical engineering from a Canadian university. ${ }^{1}$ It presents data on the current income of these men and traces the growth in their earnings from the time they graduated. Regression analysis is used to examine the impact of various independent variables on incomes and to determine the amount of explained variation in such earnings. Finally, other factors related to income are considered, including the relationship between mobility and salary improvement and a comparison between the income of Canadian engineers and that of other Canadians and United

Electrical engineers who received their degrees from Canadian universities in the same year show wide variation in the amount of their current earnings. This study finds the explanation for this dispersion in the nature of the work performed, organizational settings, and quality of performance. Being one's own boss, it is revealed, does not result in immediate gains, but pays off in the long run. Technical activity is remunerative in the early years after graduation, but in later years a managerial position offers greater financial reward.

Andrew C. Gross is assistant professor, College of Business Administration, The Cleveland State University. Financial aid for this study was received from the Canadian Department of Labour, Canadian Department of Manpower and Immigration, Center for Community Studies of the University of Saskatchewan, and the Dominion Bureau of Statistics.-EDrTor
States engineers. The present article is based on a larger study which dealt with engineering manpower in Canada. ${ }^{2}$

\section{Income Patterns and Growth of Earnings}

Mean annual earnings of 1954, 1959, and 1964 electrical engineering graduates of Canadian universities, including self-employed persons and those residing abroad, were about $\$ 11,150, \$ 9,250$, and $\$ 6,575$, respectively, as of 1965.3 Corre-

${ }^{1}$ Mail interviews were conducted with individuals who received bachelor's degrees in electrical engineering in 1954, 1959, and 1964 from a Canadian university. Of a total of 1,187 such graduates, 819 or $70 \%$ responded. The choice of this branch and the specific years was dictated by several considerations: relative homogeneity of education; standardization for years of experience; existence of an earlier pilot study of 1954 graduates, by the Department of Labour; growing importance of electrical engineering; and the author's background in this field.

${ }^{2}$ Andrew C. Gross, "Engineering Manpower in Canada," (Ph.D. dissertation, The Ohio State University, 1968). Four major areas were investigated: sources of engineering manpower, patterns of formal education for the profession, labor market experience, and patterns of utilization of young engineering graduates. In addition to the mail survey, personal interviews were conducted with engineers in four large corporations and historical data were analyzed and synthesized from 1891 to 1961 .

${ }^{3}$ Modal values were $\$ 9,850, \$ 8,200$, and $\$ 6,275$; median earnings in 1965 were $\$ 10,600, \$ 8,825$, and $\$ 6,425$, respectively. These figures are based on ungrouped data, while the figure is based on grouped data. 
Figure. Relative Histogram, Annual Earnings, Canadian Electrical Engineering Graduates, 1965.
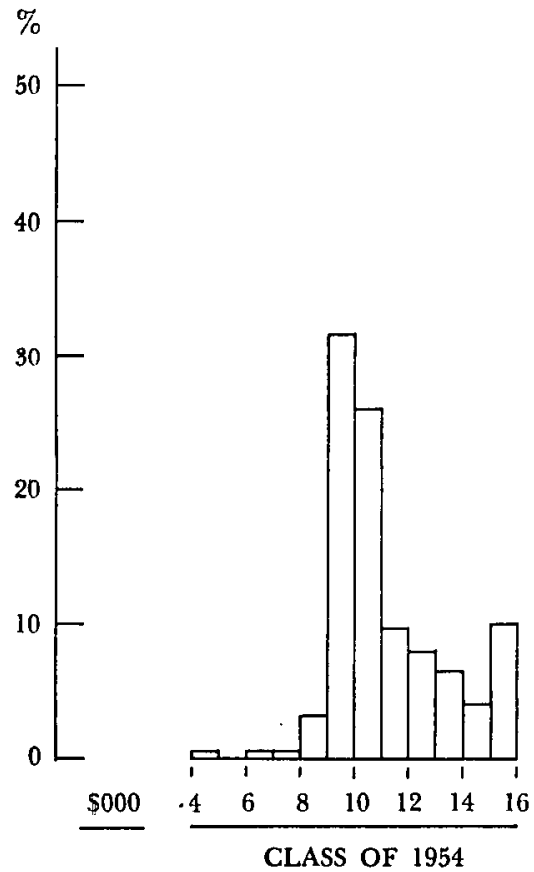

$$
\mathbf{n}=155
$$

sponding figures for those graduates from the three classes who were wage earners and resided in Canada were about $\$ 10,650, \$ 8,900$, and $\$ 6,475$, respectively. (Since self-employment and residence outside Canada were key factors contributing to higher earnings, it was decided to analyze separately, where appropriate, the salaries of those graduates who were Canadian wage earners. This latter group constitutes about 80 percent of the respondents-see the last line of Table 3 for exact numbers.) The coefficient of variation was stable in both cases: approximately 19 percent for the first three categories and about 15 percent for the last three groups. The figure shows percentage distribution of 1965 salaries for all members of the three graduating classes by $\$ 1,000$ intervals. All salaries above $\$ 15,000$ were treated

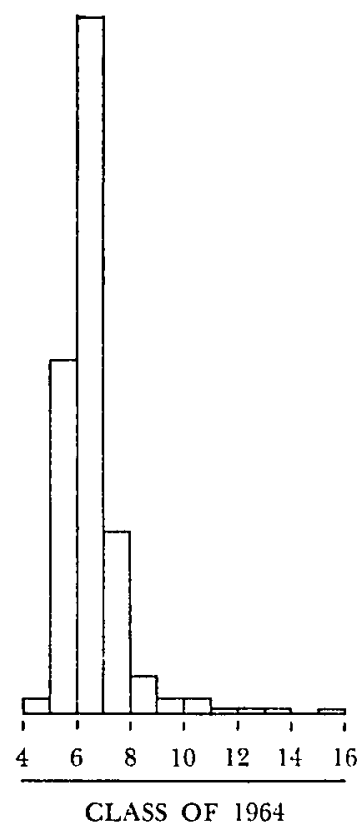

$\mathbf{n}=321$

$\mathrm{n}=\mathbf{2 5 5}$

as being at the midpoint of the $\$ 15,000$ $\$ 16,000$ interval. A slight bias was thereby introduced in the calculation of mean earnings, but this is likely to be negligible for 1959 and 1964 graduates and relatively minor even for 1954 class members. ${ }^{4}$ As expected, income distribution for each class is unimodal and positively skewed. The figure for the 1964 class is more leptokurtic than for the other two groups, since there has been much less time in which differences in

IIn a sense the procedure is both desirable and necessary: open-ended distributions would not allow calculation of means and standard deviations, while use of actual values for very high salaries would distort mean earnings considerably. Of a total of 443 engineering graduates of all branches from the 1954 class, only 3.2 percent belonged to a category for which the median salary was $\$ 14,800$ or higher-see Report on Salaries, 1965 (Ottawa: Canadian Council of Professional Engineers, 1965), pp. 2-4. 
the quality of labor or in other factors could manifest themselves. Despite this, there is as much variation in income for this group on a relative basis as there is for the other two classes (see above); it is this variation on which the regression analysis will be used.

Mean starting salaries were $\$ 4,300$, $\$ 5,375$, and $\$ 5,600$ for 1954,1959 , and 1964 graduates, upon leaving college. By the time of the survey, these men had spent about 11,6 , and 1 year in full-time employment. Using these figures, current incomes cited before, and compound interest tables, the average annual growth in salaries can be computed. This figure turns out to be 9 percent for both 1954 and 1959 graduates and 15 percent for 1964 class members. The growth in earnings is slightly understated for two reasons: the artificial salary ceiling of $\$ 15,500$ imposed and the fact that initial salaries reflect income received on starting the first job, regardless of whether this occurred immediately after receiving the bachelor's degree or following graduate schooling. Even the 9 percent figure is relatively very high: it is approximately double the annual percentage change in average weekly wages and salaries of all Canadian wage earners during the same period. 5 As will be discussed, this represents a reversal of trends observed between 1931 and 1951. It is also clear from the above figures that starting salaries for engineering graduates increased more sharply in the 1954-1959 period than during the 19591964 interval. This finding substantiates tentative conclusions drawn earlier by

\footnotetext{
"See "Statistical Tables," Canadian Statistical Review, Vol. 41, No. 8 (August 1966), p. 24; and Canadian Statistical Review: Historical Summary (Ottawa Dominion Bureau of Statistics, 1963), p. 35. Note that exclusion of self-employed graduates would not change the $9 \%$ figure significantly.
}

the OECD. ${ }^{6}$ Finally, it seems that either salary increases became smaller as the graduates grew older or that conditions permitted payment of large salary increases to very young graduates in the mid-1960's. 7

Distribution of salaries earned by members of the three graduating classes by selected characteristics (occupation, industry, etc.) are not shown here. However, certain interesting findings did emerge from such tabulations. 8 First, managerial occupation or executive function proved to be of differential advantage in earnings only after some years of employment. Specifically, research, design, and production functions, but not executive activity, have led to higher remuneration during the graduate's earliest years in the labor force. If creativity in science and engineering is indeed strongest between the ages of 22 and 32 , as is often claimed, ${ }^{9}$ then apparently this quality is being rewarded at the appropriate time. Second, it was found that manufacturing, trade, and selected service organizations consistently offered a slight edge in remuneration,

'Wages and Labour Mobility (Paris: Organization for Economic Co-operation and Development, 1965), pp. 128-129. Enrollment figures differ in this volume from those in Canadian government publications; "first year engineering enrollment," a term used by the OECD is misleading, since many freshmen do not have a declared major (or they change majors frequently).

'For an analysis, see W. L. Hansen, "Professional Engineers: Salary Structure Problems," Industrial Relations, Vol. 2, No. 3 (May 1963), pp. $42-44$.

${ }^{8}$ Some of these are reported here because in regression analysis many characteristics are represented by dummy variables, and hence a detailed breakdown, possible in one-way tables, cannot be realized.

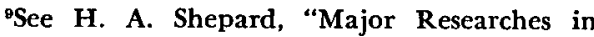
Creativity," Research Management, Vol. 2, No. 4 (Winter 1959), pp. 203-220; and H. C. Lehman, Age and Achievement (Princeton, N.J.: Princeton University Press, 1953). 
while the opposite held true for utilities and various levels of government. Third, graduates from an English-language or a highly rated university had no advantage in income earned over those from a French-language or a less highly rated school, other things being equal.

\section{Determinants of Income}

Although it is possible to hold one explanatory variable constant while the variation of salary with another is examined, such techniques have definite limitations. Results obtained from oneway (and even two- or three-way) classifications are liable to be distorted by confounding and interaction. Multiple regression analysis provides an opportunity to assess the relative contributions of the various independent variables to the dependent variable, in this case, annual salary. The technique has been used once before to study the salary structure of Canadian engineers and scientists. This was in the pioneering work of G. Rosenbluth, who used 1951 data from the Department of Labour. ${ }^{10}$ The most salient difference between his work and the present one is that while years of experience proved to be the most important of four independent variables in Rosenbluth's analysis, in the following analysis this variable is omitted by the selection of specific years of graduation. Thus, the question asked here is both more interesting and more difficult: Why do current earnings of members of a given graduating class, all of whom specialized in the same curriculum, differ from each other? This question is considered separately for the three classes and then also for that subgroup in each class whose members are wage earners residing in Canada.

The independent variables used in the multiple linear regression analysis are identified, their construction is explained, and their expected effect on income is given in Table 1 . While the-

\footnotetext{
${ }^{10} \mathrm{G}$. Rosenbluth, "Salaries of Engineers and Scientists, 195 I" in E. F. Beach and J. C. Weldon, eds., Papers 1960-Canadian Political Science Association Conference on Statistics (Toronto: University of Toronto Press, 1962), pp. 137-182.
}

Table 1. Variables Used in Multiple Linear Regression Analysis, Canadian Electrical Engineering Graduates, 1965.

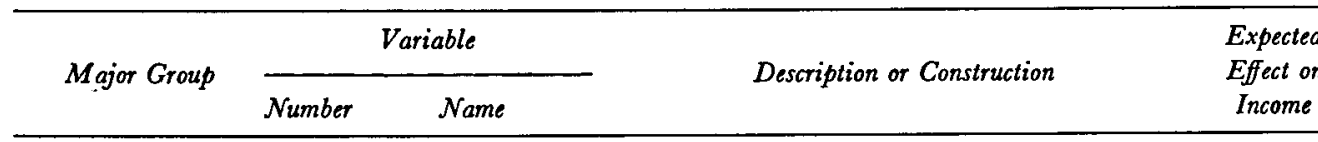

1 Fringe benefits

Compensating differences

Quality of labor

\section{Satisfaction- utilization score}

3 Initial salary

4 Activity and awareness index
Total number of fringe benefits received in full or in part, maximum score 10 , minimum score 0

Sum total of scores given on 11 questions relating to satisfaction and utilization; maximum score 1100 , minimum score 550

Remuneration received at start of first job; in hundreds of dollars

Composite of journals read, conferences attended, and articles recalled; maximum score 34 , minimum score 0 


\begin{tabular}{|c|c|c|c|c|}
\hline \multirow{2}{*}{ Major Group } & \multicolumn{2}{|r|}{ Variable } & \multirow{2}{*}{ Description or Construction } & \multirow{2}{*}{$\begin{array}{l}\text { Expected } \\
\text { Effect on } \\
\text { Income }\end{array}$} \\
\hline & Number & Name & & \\
\hline & 5 & Ambition & $\begin{array}{l}1 \text { if wants to be successful, } 0 \text { if wants to be in- } \\
\text { dependent or well liked }\end{array}$ & + \\
\hline \multirow[t]{8}{*}{$\begin{array}{l}\text { Quality } \\
\text { of labor }\end{array}$} & 6 & $\begin{array}{l}\text { Academic } \\
\text { performance }\end{array}$ & $\begin{array}{l}\text { Overall undergraduate grade average; maxi- } \\
\text { mum score } 100, \text { minimum score } 50\end{array}$ & + \\
\hline & 7 & Hours worked & $\begin{array}{l}\text { Total number of hours worked per week, in- } \\
\text { cluding those at home }\end{array}$ & + \\
\hline & 8 & $\begin{array}{l}\text { Responsibility } \\
\text { index }\end{array}$ & $\begin{array}{l}\text { Length of time during which individual acts } \\
\text { on own (without direction); maximum } \\
\text { score } 8 \text { (over } 4 \text { months), minimum score } 1 \\
\text { ( } 8 \text { hours or less) }\end{array}$ & + \\
\hline & 9 & $\begin{array}{l}\text { Highest } \\
\text { graduate } \\
\text { degree (if any) }\end{array}$ & $\begin{array}{l}0 \text { if B.S. only, } 1 \text { for diploma, } 2 \text { for Master's, } \\
4 \text { for Ph.D., M.D., Sc.D. }\end{array}$ & + \\
\hline & 10 & Mobility & $\begin{array}{l}\text { Total number of job (interemployer) shifts } \\
\text { made since graduation }\end{array}$ & \\
\hline & 11 & $\begin{array}{l}\text { Professional } \\
\quad \text { registration }\end{array}$ & $\begin{array}{l}1 \text { if registered professional engineer, } 0 \text { other- } \\
\text { wise }\end{array}$ & + \\
\hline & 12 & Class of worker & 1 if self-employed, 0 otherwise & + \\
\hline & 13 & $\begin{array}{l}\text { Substitutability } \\
\text { index }\end{array}$ & $\begin{array}{l}\text { Ability of others to perform same work; maxi- } \\
\text { mum score 18, minimum score } 6 \text { (with } \\
\text { higher score indicating lower likelihood) }\end{array}$ & + \\
\hline \multirow[t]{5}{*}{ Nature of work } & 14 & $\begin{array}{l}\text { Different } \\
\text { functions }\end{array}$ & $\begin{array}{l}\text { Total number of different functions per- } \\
\text { formed; maximum score } 10 \text {, minimum } \\
\text { score } 1\end{array}$ & + \\
\hline & 15 & Function & $\begin{array}{l}1 \text { if executive-administrative is principal ac- } \\
\text { tivity, } 0 \text { otherwise }\end{array}$ & + \\
\hline & 16 & Supervision & $\begin{array}{l}\text { Total number of men supervised directly and } \\
\text { indirectly }\end{array}$ & + \\
\hline & 17 & Occupation & 1 if managerial occupation, 0 otherwise & + \\
\hline & 18 & Industry & $\begin{array}{l}1 \text { if mining, construction, manufacturing, } \\
\text { trade, finance, and consulting services; } 0 \text { if } \\
\text { utilities, government, education }\end{array}$ & + \\
\hline \multirow{3}{*}{$\begin{array}{l}\text { Institutional } \\
\text { and organiza- } \\
\text { tional setting }\end{array}$} & 19 & $\begin{array}{l}\text { Job offers } \\
\text { received }\end{array}$ & $\begin{array}{l}\text { Total number of job offers received in past } \\
12 \text { months }\end{array}$ & + \\
\hline & 20 & $\begin{array}{l}\text { Months in } \\
\text { present job }\end{array}$ & $\begin{array}{l}\text { Total number of months spent with current } \\
\text { employer }\end{array}$ & + \\
\hline & 21 & $\begin{array}{l}\text { Residency } \\
\text { status }\end{array}$ & 1 if not a resident of Canada, 0 if a resident & + \\
\hline $\begin{array}{c}\text { Dependent } \\
\text { variable }\end{array}$ & \multicolumn{2}{|c|}{$\begin{array}{l}\text { Annual salary in } \\
1965\end{array}$} & $\begin{array}{l}\text { Gross income from salaries and wages, in } \\
\text { hundreds of dollars }\end{array}$ & \\
\hline
\end{tabular}


oretical considerations can readily suggest major factors which influence income,11 variables were not always available in the desired form or in the desired relationship corresponding to a specific portion of the theory. Thus, some of the factors had to be represented by proxy, index-type, or dummy variables, while others simply were omitted. ${ }^{12}$ Six estimating equations or "runs" were constructed as follows: runs $1 \mathrm{la}, 2 \mathrm{a}$, and 3a for all 1954, 1959, and 1964 electrical engineering graduates and runs $4 a, 5 a$, and $6 a$ for the corresponding subgroups whose members were wage earners residing in Canada. In each run a highly significant value of the F-statistic was found, indicating the existence of a relationship between the dependent variable and the entire set of independent variables. In the first three runs the amount of explained variation was about 50 percent, while in the last three cases it was approximately 40 percent. ${ }^{13}$ The variables used proved to be a somewhat better set of explanatory factors for older than for more recent graduates.

The amount of explained variation in any of the above runs is certainly a much

${ }^{11}$ For a more detailed discussion of these points, see C. Kerr, "Wage Relationships: The Comparative Impact of Market and Power Forces," in J. T. Dunlop, ed., The Theory of Wage Determination (London: Macmillan Co., 1957), pp. 173-193; L. G. Reynolds, Labor Economics and Labor Relations, 4th ed. (Englewood Cliffs, N. J.: Prentice-Hall, Inc., 1964), p. 499; and $\mathrm{K}$. W. Rothschild, The Theory of Wages (New York: Macmillan Co., 1954), pp. 73-76.

12Proxy variables here refer to "imperfect substitutes" (for example, academic grade for ability); index-type variables are really "composites." For the use of dummy variables, see D. B. Suits, "The Use of Dummy Variables in Regression Equations," Journal of the American Statistical Association, Vol. 52, No. 280 (December 1957), pp. 548-551.

${ }^{18}$ The coefficient of determination, $R^{2}$ was 0.48 , $0.54,0.43,0.43,0.37$, and 0.34 , for the six runs, respectively. higher figure than the 21 percent reported by Rosenbluth for Canadian electrical engineers as of 1951.14 The results here are, in fact, more impressive than such comparison of the coefficients of determination would indicate, since variation within experience categories is being explained. Admittedly, some of the improvement is due to the inclusion of more variables, but the amount of explained variation decreased only slightly when more than half of the independent variables were eliminated (see below). Still, this amount of explanation by the model- 40 to 50 percent-is surprisingly low, considering the number and nature of the variables included. In part, this result is due to the use of dummy variables for such important influences as occupation and industry. Inclusion of specific employer characteristics-especially rate of growth, perceived need for technical men, and profitability of the firm-possibly would have contributed much toward explaining some of the remaining variation. Similarly, using more appropriate measures for quality of labor, such as on-the-job contribution instead of academic performance, would have resulted in a higher amount of explained variation.

\section{Summary of Six Runs}

A close examination of the matrix of simple correlation coefficients in each of the six runs showed no significant association among the independent variables $(\mathrm{r} \leq 0.40)$. However, certain factors in

\footnotetext{
${ }^{14}$ Rosenbluth, "Salaries, 1951," pp. 150-153. Industry, region, function, and experience were the independent variables. His analysis of other occupational groups (civil engineers, biologists, etc.) yielded only slightly higher $R^{2}$ values, in the range of 0.25 to 0.32 . Note that the study by Rosenbluth refers to (one third of all) Canadian electrical engineers, not to Canadian electrical engineering graduates.
} 
Table 2. Run 1-b: Results of Regression Analysis, Present Salary (1965) and Related Key Variables, Canadian Electrical Engineering Graduates, Class of 1954, all Full-Time Workers.

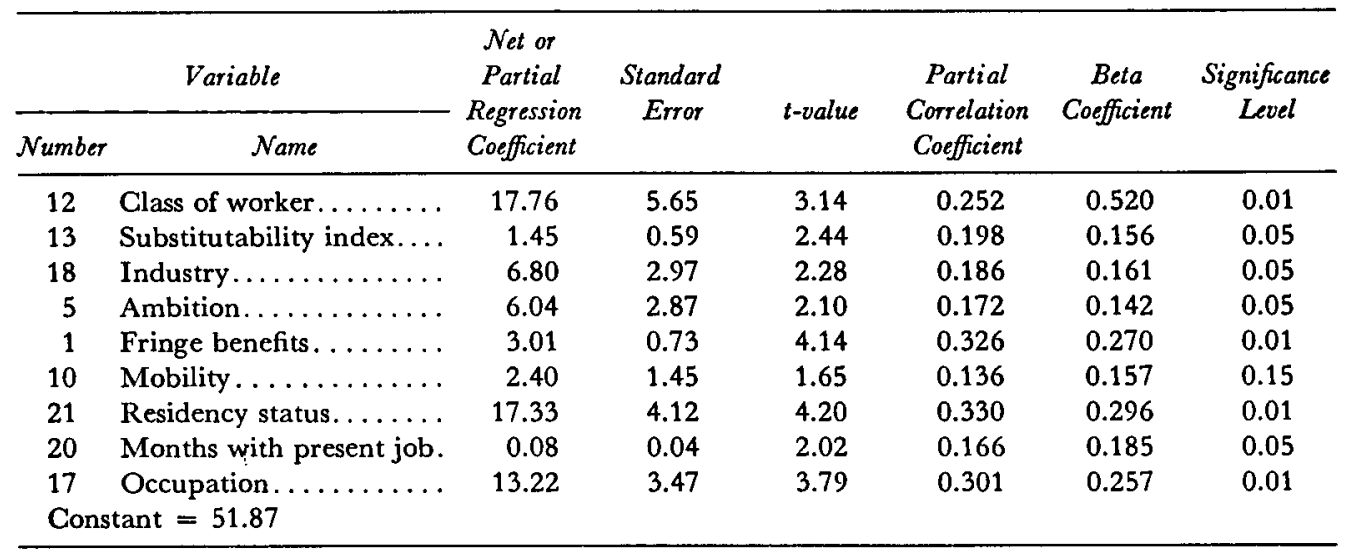

Coefficient of multiple determination, $\mathrm{R}^{2}=0.432$.

Regression variance/Residual variance, $F=12.29(p<.01)$.

Standard error of estimate, $S_{y_{1}}=16.38$.

Number of respondents, $\mathrm{n}=155$.

each of the six estimating equations, i.e., runs $1 \mathrm{a}$ to $6 \mathrm{a}$, could be characterized as weak explanatory variables (for example, activity index or number of different functions performed). These showed a low degree of correlation with the dependent variable; they had relatively low t-values, low partial correlation coefficients, and low beta coefficients. ${ }^{15}$ Since there was no theoretical objection to excluding such relatively unimportant and unreliable variables, this was done, and the estimating equations (now denoted as runs $1 \mathrm{~b}$ to $6 \mathrm{~b}$ ) were calculated with the nine remaining "key" variables. The key variables were not identical from run to run, but there was a considerable overlap as expected. Data for run $\mathrm{lb}$ are shown in Table 2 and can be con-

${ }^{15}$ On inclusion and exclusion of variables, see M. Ezekiel and K. Fox, Methods of Correlation and Regression Analysis, 3rd ed. (New York: John Wiley \& Sons, Inc., 1959), pp. 194-196. For a similar example of eliminating variables on this basis, see A. Al-Samarrie and H. P. Miller, "State Differentials in Income Concentration," American Economic Review, Vol. 57, No. I (March 1967), pp. 67-71. sidered typical in terms of confidence level, t-values, and other coefficients. A summary of all six runs, showing key variables, amount of explained variation, and number of respondents in each case, is presented in Table 3. Data from these tables and from the tables for the other runs, along with supporting information (not shown here), can be summarized and interpreted as follows.

1. The value of the calculated F-ratio remained significant in all six runs, indicating the existence of a relationship between the dependent variable and the respective set of key variables. The value of $\mathrm{R}^{2}$, the coefficient of determination, decreased relatively little in each case. Thus, the omitted variables contributed only small amounts to the explanation of variation in income. As a result of the elimination of weak explanatory variables, there has been a marked improvement in the confidence level of many of the key variables.

2. Differences in (a) quality of labor, (b) nature of work performed, and (c) 
Table 3. Summary of Regression Analysis: Canadian Electrical Engineering Graduates, Present Salary (1965) and Related Key Variables, Significance Levels, and Signs of Regression Coefficients, Runs 1-b to 6-b.

\begin{tabular}{|c|c|c|c|c|c|c|c|}
\hline & & 1954 & lass & 1959 & lass & 1964 & Tlass \\
\hline Number & Name & $\begin{array}{l}F T W^{*} \\
\text { Run } 1 b\end{array}$ & $\begin{array}{l}\text { CWE } † \\
\text { Run } 4 b\end{array}$ & $\begin{array}{l}F T W^{*} \\
\text { Run } 2 b\end{array}$ & $\begin{array}{l}\text { CWE } † \\
\text { Run } 5 b\end{array}$ & $\begin{array}{l}F T W^{*} \\
R u n 3 b\end{array}$ & $\begin{array}{l}\text { CWE } \dagger \\
\text { Run } 6 b\end{array}$ \\
\hline 1 & Fringe benefits. . . . . . . & $(+) .01$ & $(+) .10$ & & & (+) .01 & $(+) .01$ \\
\hline 2 & $\begin{array}{l}\text { Satisfaction-utilization } \\
\text { score } \ldots \ldots \ldots \ldots \ldots \ldots\end{array}$ & & (t) .10 & $(+) .01$ & $(+) .01$ & & \\
\hline 3 & Initial salary $\ldots \ldots \ldots \ldots$ & & & & & $(+) .01$ & $(t) .01$ \\
\hline 4 & 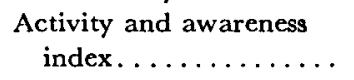 & & & & & & \\
\hline 5 & Ambition. . . . . . . . . . & $(+) .05$ & $(+) .10$ & & & & \\
\hline 6 & Academic performance. & & (+) .05 & $(+) .10$ & $(+) .01$ & & \\
\hline 7 & Hours worked......... & & & & & (+) .01 & $(+) .01$ \\
\hline 8 & Responsibility index..... & & & & $(+) .20$ & $(+) .01$ & \\
\hline 9 & Highest graduate degree. & & & & $(-) .10$ & & \\
\hline 10 & Mobility $\ldots \ldots \ldots \ldots \ldots$ & (+) .15 & $(+) .20$ & $(+) .01$ & & & \\
\hline 11 & Professional registration.. & & $(+) .01$ & & & $(+) .01$ & $(t) .01$ \\
\hline 12 & Class of worker......... & (+) .01 & n.a. & $(+) .01$ & n.a. & $(-) .01$ & n.a. \\
\hline 13 & Substitutability index.... & $(+) .05$ & & & & & \\
\hline 14 & Different functions...... & & & & & & \\
\hline 15 & Function $\ldots \ldots \ldots \ldots$ & & $(+) .10$ & & & & \\
\hline 16 & Supervision. . . . . . . & & & & $(+) .01$ & $(-) .20$ & \\
\hline 17 & Occupation........... & (+) .01 & $(+) .01$ & $(+) .01$ & $(+) .01$ & $(-) .20$ & \\
\hline 18 & Industry $\ldots \ldots \ldots \ldots \ldots$ & $(+) .05$ & & $(+) .15$ & $(+) .30$ & & (+) .10 \\
\hline 19 & Job offers received ...... & & & $(+) .01$ & $(+) .05$ & & $(+) .05$ \\
\hline 20 & Months in present job... & $(+) .05$ & $(+) .30$ & $(+) .01$ & $(+) .10$ & & \\
\hline 21 & Residency status....... & (+) .01 & n.a. & $(+) .01$ & n.a. & $(+) .01$ & n.a. \\
\hline$R^{2}-R u$ & uns $1 \mathrm{~b}$ to $6 \mathrm{~b} . \ldots \ldots \ldots$ & .43 & .39 & .51 & .36 & .42 & .32 \\
\hline & umber of variables used). & (9) & (9) & (9) & (9) & (9) & (6) \\
\hline$R^{2}-R u$ & uns $1 \mathrm{a}$ to $6 \mathrm{a} \ddagger \ldots \ldots \ldots$ & .48 & .43 & .54 & .37 & .43 & .34 \\
\hline & umber of variables used). & (21) & (19) & (21) & (19) & (21) & (19) \\
\hline$n-N u r$ & mber of respondents. & 155 & 121 & 255 & 224 & 321 & 309 \\
\hline
\end{tabular}

*FTW $=$ Electrical engineering graduates working full time at time of survey.

†CWE $=$ Subset of previous group, members of which reside in Canada and are wage earners.

†Shown for reference only.

n.a. = not applicable.

institutional and organizational settings have all contributed to differences in salaries earned. The following variables proved to be significant (at the .05 level) and to have positive regression coefficients in at least two cases: (a) undergraduate academic performance, hours worked, and professional engineer license, (b) self-employed status and occupation, and (c) number of job offers received in the past year, number of months spent with present employer, and residency outside Canada. Compensating differences (i.e., number of fringe benefits received, satisfactionutilization score, and initial salary) had positive coefficients thus supporting findings of previous studies that they accompany rather than substitute for high income. 
3. For 1954 and 1959 graduates, selfemployed status and residency outside Canada were highly significant and important variables: either could mean an additional $\$ 1,600$ to $\$ 2,100$ income per year. Graduates from these classes in managerial occupations typically earned an added $\$ 1,300$ per year. ${ }^{16}$ However, these variables had little influence on the earnings of the 1964 class members; relatively fewer men were in self-employment, outside Canada, or in managerial occupations. For 1964 graduates, hours worked per week were a significant variable; extra effort expended at the early stage of one's career apparently is noticed. Initial salary also played a major influence for these recent graduates, a finding similar to that reported for certain U.S. professionals. ${ }^{17}$

4. The positive regression coefficients for both the number of job shifts made and the number of months spent with the current employer may seem surprising at first. They would indicate that a valuable employee is one who has "moved around" gaining varied skills, but has now "settled in" with his present organization. There is weak or no correlation between possession of an advanced degree and current income; many persons holding graduate degrees apparently accepted positions in relatively lowpaying industries or occupations. ${ }^{18}$ The

\footnotetext{
${ }^{10}$ The net or partial regression coefficient in Table 2 represents the differential effect of the independent variable on the dependent one, in hundreds of dollars.

${ }^{17}$ G. J. Stigler, "Information in the Labor Market," Journal of Political Economy, Vol. 70, No. 5, Part 2, (October 1962), p. 96 . The relationship definitely becomes weaker with the passage of years.

${ }^{18}$ Not so in the U.S.; see "Degrees Beget Dollars," Professional Engineer and Engineering Digest, Vol. 27. No. 10 (October 1966), p. 51, reporting the results of a University of Illinois survey of its 1960 engineering graduates. Explanation: U.S. graduates with advanced degrees
}

importance of number of job offers received in the past year by the 1959 graduates, but not other groups, seemed to indicate the former were at the peak of their own "marketability" six years after graduation, and they used this lever for obtaining higher salaries from their present employers. The positive contribution of the responsibility index and professional registration to the earnings of the 1964 graduates must be interpreted with care; they are likely to be proxy variables for the experience of the few older men in the group who did technical work prior to entering college.

5. The removal of class of worker and residency status decreased the amount of explained variation in income and also influenced the relative importance of some of the remaining variables. Thus, for the three groups of Canadian wage earners, individual qualifications have definitely risen in their explanatory power: outstanding academic performance and professional registration now make a greater positive contribution to annual earnings. A managerial occupation is still a significant source of additional income, again indicating that executives are better rewarded than those who remain as technical men. This seems to run counter to the dual ladder (or parallel path) of advancement professed by most corporations. As before, forces influencing earnings of relatively older graduates differ somewhat from factors which are significant for the 1964 class.

\section{Mobility and Salary Changes}

The number of job shifts made had a positive, though not always major, influ-

have a higher concentration in private industry than do their Canadian counterparts, especially in manufacturing. Furthermore, the tertiary sector in the U.S. may be more competitive with the secondary sector than is the case in Canada. 
Table 4. Number of Men Moving and Change in Salary upon Moving, Canadian

Electrical Engineering Graduates, by Year of Moving.

\begin{tabular}{|c|c|c|c|c|c|c|c|c|c|c|c|c|c|}
\hline \multirow{2}{*}{\multicolumn{2}{|c|}{$\begin{array}{c}\text { Change in Salary } \\
\text { upon Moving } \\
\$\end{array}$}} & \multicolumn{12}{|c|}{ rear of Moving } \\
\hline & & 1954 & 7955 & 7956 & 1957 & 1958 & 1959 & 1960 & 1961 & 1962 & 1963 & 1964 & 1965 \\
\hline \multirow{10}{*}{ 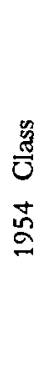 } & $\begin{array}{l}+5,000 \&+ \\
+4,000\end{array}$ & & 1 & & 1 & & & & & & 2 & 2 & 1 \\
\hline & $+3,000$ & & & 1 & 1 & & 2 & 1 & & 2 & & 2 & \\
\hline & $+2,000$ & & 4 & 4 & 4 & & 3 & 2 & & 3 & & 2 & 2 \\
\hline & $+1,000$ & 3 & 6 & 7 & 6 & 1 & 7 & 3 & 4 & 2 & 4 & 2 & 4 \\
\hline & 0 & 2 & 7 & 6 & 5 & 7 & 6 & 4 & 5 & 7 & 4 & 2 & \\
\hline & $-1,000$ & 1 & & 2 & & 2 & 1 & 2 & 2 & 1 & & 1 & \\
\hline & $-2,000$ & 1 & 1 & & 2 & 1 & 1 & & & 1 & & 2 & 1 \\
\hline & $-3,000$ & & & 1 & 1 & & & & & & & 1 & \\
\hline & $-4,000$ & & & & & & 1 & & & & & & \\
\hline & $-5,000 \&-$ & & & & & 1 & 1 & 2 & & & & & 1 \\
\hline \multirow{11}{*}{ ณू } & $+5,000 \&+$ & & & & & & & & 1 & & & 1 & 1 \\
\hline & $+4,000$ & & & & & & & & 1 & & & 1 & 1 \\
\hline & $+3,000$ & & & & & & & 2 & & & & 1 & 1 \\
\hline & $+2,000$ & & & & & & 2 & 1 & 1 & 4 & 5 & 3 & 5 \\
\hline & $+1,000$ & & & & & & 1 & 2 & 7 & 13 & 7 & 5 & 9 \\
\hline & 0 & & & & & & 4 & 15 & 14 & 18 & 8 & 9 & 6 \\
\hline & $-1,000$ & & & & & & 1 & & & 4 & 2 & & 2 \\
\hline & $-2,000$ & & & & & & & & & 1 & & & 1 \\
\hline & $-3,000$ & & & & & & 1 & & & & & & \\
\hline & $-4,000$ & & & & & & & & & & & & \\
\hline & $-5,000 \&-$ & . & & & & & & & & & & & 1 \\
\hline \multicolumn{14}{|c|}{ Unemployment } \\
\hline & ate $-\% \ldots$ & 4.6 & 4.4 & 3.4 & 4.6 & 7.1 & 6.0 & 7.0 & 7.2 & 6.0 & 5.5 & 4.7 & 3.9 \\
\hline
\end{tabular}

ence on current income; the specific changes in salaries obtained on moving have not been investigated until now. Table 4 shows number of men moving and change in salary after moving on a year-by-year basis for the mobile members of the classes of 1954 and 1959. No distinction is made between voluntary and involuntary job separations for two reasons: the latter accounted for only a small proportion of all moves, and a study of engineers and scientists found no differences in wage changes according to whether the move was voluntary or not. ${ }^{19}$ Movement between employed and

\footnotetext{
${ }^{10}$ John E. Parker, "Labor Market Behavior of Engineers and Scientists: an Analysis in The Aerospace Industry" (Ph.D. dissertation, University of Wisconsin, 1963), pp. 158-159.
}

self-employed status was included, but that between full-time and part-time positions was excluded from Table 4.

In the class of 1954, about half of the movers benefited from making a job shift, 31 percent showed no change in remuneration, and 18 percent accepted cuts in salaries of $\$ 1,000$ or more. Corresponding figures for the 1959 class were similar: 45, 44, and 11 percent, respectively. Among mobile aerospace engineers and scientists in the U.S., almost two thirds obtained higher compensation on moving during 1953-1962.20 Parnes concluded that from 50 to 60 percent of U.S. workers, most of them in lower level occupations, achieved an immediate

solbid. 
financial gain from changing jobs during the 1930's and 1940's. ${ }^{21}$ The Canadian figure is thus somewhat less than the percentages reported in the U.S., but the present study ignored changes of less than $\$ 1,000$. The different structure of the two labor markets also can account in part for the difference in proportion of those who achieved an improvement in income after moving. ${ }^{22}$

An analysis of individual questionnaires revealed that three distinct groups of Canadian graduates accepted salary decreases on changing positions. In the first category were those who entered self-employment by establishing their own firms (as opposed to joining familyowned enterprises). If these men could remain in a self-employed status for over two years, they almost invariably compensated themselves for their earlier losses. Another group accepting pay cuts included those who originally had taken a "high venture" position. Having earned substantial wages and benefits, usually at remote locations, these men were eager to return to less lucrative but more stable and familiar surroundings. Finally, some men chose to take salary cuts either to escape from a disagreeable work environment or in hope of opportunities for advancement in the long run.

Additional conclusions may be drawn from Table 4 and from related information not shown here. First, the experience of mobile graduates shows that

\footnotetext{
${ }^{21}$ Herbert S. Parnes, Research on Labor Mobility (New York: Social Science Research Council, 1954), p. 177.

${ }^{22}$ For example, the relatively strong demand for aerospace engineers in the U.S. had no counterpart in Canada. There are major differences between the two countries in terms of competition, availability of labor market information, role of private employment agencies, federal programs, etc.
}

salary increases are harder to obtain when general economic conditions are not favorable. The relatively high unemployment rates of 1958 and 1961 influenced both the number of movers and their immediate salary gains. Second, no clearcut relationship was found between type of job shift and amount of salary increase. For example, 1959 graduates making a change in occupation did much better financially than those who changed industries, but this was not the case for 1954 class members. Third, the information on salary changes of mobile men appears to be consistent with reported reasons given for job separations. Wages and other economic factors accounted for about 45 percent of all separations, according to the graduates.

\section{Income of Engineers: Additional Considerations}

Six other aspects relating to earnings of engineers have been investigated:

1. Analysis of published data in Canada and data from the primary survey neither support nor refute the hypothesis that size of firm and engineering salaries are positively correlated.

2. During the 1960's, starting salaries for electrical engineering graduates and mean earnings of experienced electrical engineers were practically identical to corresponding measures for engineering graduates and engineers of all branches combined. In this sense, electrical engineering graduates are typical of all engineering graduates.

3. At least 80 percent of the graduates in each of the three classes received vacation, life insurance, hospitalization, and retirement pay from their employers as fringe benefits; about 50 percent received tuition refunds for technical courses; and only 30 percent received similar compensation toward nontechnical course 
Table 5. Years of Experience or Responsibility Levels vs. Salary of Engineers, Canada and U.S.A., 1964 and 1966.

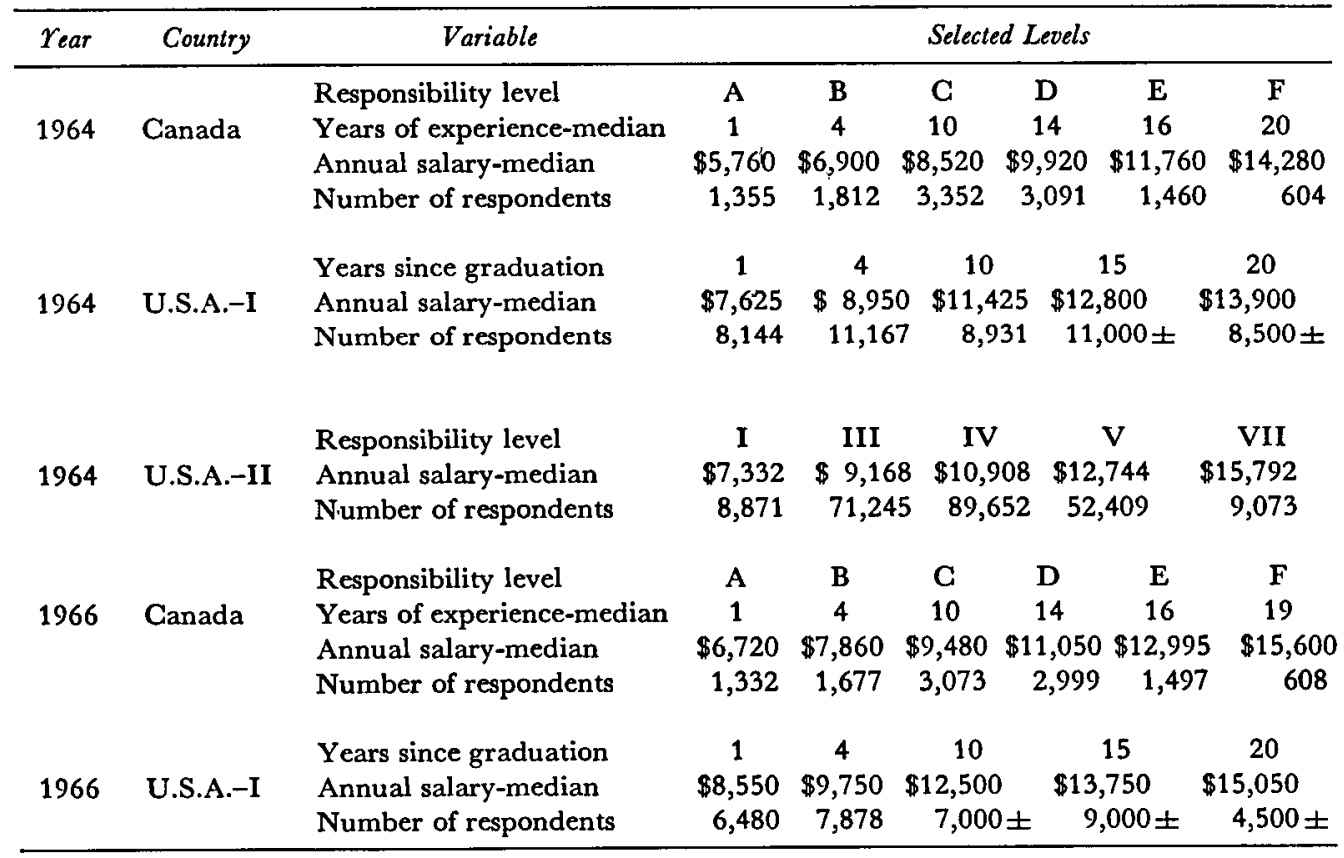

Source: For Canada: Report on Salaries, 1964 and Report on Salaries, 1966 (Ottawa: Canadian Council of Professional Engineers, 1964, 1966).

For U.S.A.: I-Professional Income of Engineers, 1964 and Professional Income of Engineers, 1966-1967 (New York: Engineering Manpower Commission, 1964, 1967), II-National Survey of Professional, Administrative, Technical, and Clerical Pay, Feb.-March 1964 (Washington: Bureau of Labor Statistics, 1964).

work. Graduates entering managerial and military occupations received more fringe benefits than those remaining in the professional category. Transportation and communication companies were the most generous in their fringe benefit policies.

4. Despite claims to the contrary, relative increases in salaries were significantly higher for younger than for older engineering graduates."23 Such "salary

\footnotetext{
Based on comparison of findings from the primary survey and data from the Canada Department of Labour vs. Report on Salaries (Ottawa: Canadian Council of Professional Engineers, yearly, 1959-1966), pp. 2-4. The CCPE obtains its data directly from large organizations only and not from individual respondents.
}

compression" appeared to be due much more to market conditions than to technological obsolescence of older men. ${ }^{24}$ But fringe benefits show some correlation with years of experience and hence mitigate the impact of the narrowing of salary differentials.

5. As Table 5 shows, at the level of 1 to 10 years of experience, median U.S. engineering salaries exceeded their Canadian counterparts by about 30 percent during the 1960's. At the same time, at the 15-year experience mark the differential was only 16 percent, and beyond the 20-year level there was practically no difference in median incomes earned. 
6. During the 1930-1950 period in Canada the earnings of engineers, other professionals, and managers rose more slowly than income of all workers combined; a definite reversal in this trend occurred in the 1950's. ${ }^{25}$ This finding is similar to that reported for selected professions in various Western Hemisphere countries during the same interval. ${ }^{26}$

${ }^{2}$ See, for example, Ninth Census of Canada, 1951, Vol. V, pp. 1-1 to 6-1, 21-1 to 21-2, and Tenth Census of Canada, 1961, Vol. III, part 3, pp. 9-1 to 10-2, 21-1 to 2l-3.

${ }^{20} \mathrm{~T}$. Scitovsky, “An International Comparison
Neither the level nor the trend in income of Canadian engineers compares unfavorably with the earnings of certain other professionals in that country between 1930 and 1960, although the level was somewhat lower in all of the years for which data were available. ${ }^{27}$

of the Trend of Professional Earnings," Ameri. can Economic Review, Vol. 56, No. 1 (March 1966), pp. 35-40.

"See Scitovsky, "International Comparison," pp. 35-40; Canadian Statistical Review, Historical Summary, pp. 10 and 25; and Canadian Statistical Review, Vol. 41, No. 8 (August 1966), pp. 3 and 16 . 
Copyright of Industrial \& Labor Relations Review is the property of Cornell University and its content may not be copied or emailed to multiple sites or posted to a listserv without the copyright holder's express written permission. However, users may print, download, or email articles for individual use. 